\title{
Draupadi: Revisiting the Past through the Lens of the Gendered Subaltern
}

\section{Shangsita Goswami}

\begin{abstract}
In giving voice to the tribal's quest for human rights, recognizing their place as some of the most economically and politically marginalized people in India, Mahashweta Devi's name acquires a special place. Having sympathetically observed the tribes' day-to-day existence, value system, repeated exploitation at the hands of others and the state machinery, she has tried to feel their pangs in every sphere of life from the innermost core of her sensibilities. Devi's short story, namely, Draupadi (1978) stands as a typical example where the paleonymy of the mythical heroine from The Mahabharata is employed for the 'strategic necessity' for exploring the nuances of the Naxalite movement and its close communion with the question of tribal-rights during the historical phase from 1967 to 1971 in West Bengal and India. It is one such text which has consciously attempted the relocation of the epical myth by reading against the grain and supplanting it with the modern context revealing numerous layers of structurization in relation to socio-politico-cultural ideologies. In my proposed paper tries to explore how the narrative of 'Draupadi / Dopdi' gathers contemporaneity and complexity while placed against the protagonist's existence as a tribal-subaltern-peasant-rebel and becomes a pronouncement of the mobilization of that rebellious consciousness that turns indistinguishable from the emergence of her 'gendered subaltern' ethnic self.
\end{abstract}

Keywords: Class, Race, Resistance of the Subaltern, Voices of the Marginalized, Myth.

Time and again in my writings can be found the reflection of that part of the society which I call the voiceless section of Indian Society. This particular section is not merely illiterate, half-literate and underdeveloped, it is utterly isolated from the mainstream. But without knowing this fragment of Indian society, idea of India remains beyond comprehension. (Mahasweta Devi, 1981, pp. 381-402)

When literature becomes a living platform for the dialogic communion between myth and reality, texts like Mahasweta Devi's short story, namely, Draupadi (Agnigarbha, 1978; translated by Spivak in 1981) stands as a distinct example-here the paleonymy of the mythical heroine from The Mahabharata is employed for the "strategic necessity"(Derrida) for exploring the nuances of the Naxalite movement and its close communion with the question of tribal-rights during the historical phase from 1967 to 1971 in West Bengal and India. The literary text is interwoven into the textile of the writer's activism and turns into a 'historiographic metafiction' - it consciously reads the ancient text against the grain and supplanting it with the modern context reveals numerous layers of structurization in relation to socio-politico-cultural ideologies. In my proposed paper tries to explore how the narrative of 'Draupadi / Dopdi' gathers contemporaneity and complexity while placed against the protagonist's existence as a tribal-subaltern-peasant-rebel and becomes a pronouncement of 
the mobilization of that rebellious consciousness that turns indistinguishable from the emergence of her "gendered subaltern" (Spivak, 1991, p.161) ethnic self.

Mahasweta Devi's short story Draupadi is a modern transliteration and revision of the ancient mythical text. Here we find a Santhal woman who had been given the archetypal name 'Draupadi' by the mistress of the feudal land-lord "in the usual mood of benevolence felt by the oppressor's wife toward the tribal bond servant." (Spivak, 1981, p. 387) Her mother used to work as a labourer for husking the crops under that landholder called Surya Sahu. As a tribal Draupadi was pronounced as 'Dopdi' in her locality - it is a possibility that in a tribal language the Sanskritised 'Draupadi' cannot be uttered by her people and herself, "or the tribalized form, Dopdi, is the proper name of the ancient Draupadi." (ibid, p. 387) However, she carried within her the uniqueness related to both of the names: the oppressedbold-and-proud mythic woman is merged into her representation of the exploited indigenous tribe of this country. Still, her name proposed an enigmato others as revealed in the conversation between two uniformed men:

"First Livery: What's this, a tribal called Dopdi? The list of names I brought has nothing like it! How can anyone have an unlisted name?

Second: Draupadi Mejhen.... Surja Sahu's wife gave her the name.” (Ibid, p. 392)

Seemingly, the list consisted of the names commonly found in tribal society and it was a part of that project taken by the statutory authority to define the mysterious aboriginal 'other' by limiting the vibrancy of diverse ethnicities into a monochromatic schema. It was reflected in the policies and actions of every governmental agency: "not merely the Santals but all tribals of the Austro-Asiatic Munda tribes appear the same to the Special Forces." (Ibid, p. 393)

Now, Mahasweta's Draupadi was not only a tribal, she was also a Naxalite rebel mutinying against the denial of the peasants' rights on their lands, bonded labour system and coercive feudalism which were once the hallmarks of the colonial administration but were prevalent even in post-independence India. She along with her husband, Dulna Majhi, used to work "at harvests, rotating between Birbhum, Burdwan, Murshidabad, and Bankura... Murdering Surja Sahu and his son, occupying upper-caste wells and tubewells during the drought..." (ibid, p. 392) Special Force could not grab hold of the couple and they, in the manner of trained soldiers, went on killing grain brokers, landowners, usurers, legislative officials thereby aiding the urban educated revolutionaries in their socio-political movement. But then entered Mr. Senanayak, the old Bengali army-commander, a "specialist in combat and extreme-Left politics" (393). His war-strategy was a novel one that essentially had a colonial undertone: "In order to destroy the enemy, become one" (394). With the hope of highlighting theoretically the cause of the insurgents in future days, he callously ordered for "apprehension and elimination" policy, and, with the help of the army, cordoned off the whole Jharkhani forest where the Naxal activists, both urban and rural-tribal, had taken shelter. "Soldiers in hiding guard the falls and springs that are the only source of drinking water" (394) and ambushed Draupadi's husband, Dulna, and shot him dead as he laid drinking water from the stream.

Draupadi/ Dopdi, like her mythical counterpart, had herself chosen Dulna as her husband, as known from her tale that partly occurs in Mahasweta's novel "Operation? Basai Tudu". Dopdi is described there as a strange Santhal woman with a sharp curved body and unparalleled personality, "too dark, too savage, too handsome", "having a voice slightly heavy but happy" "standing like a queen as if the entire sphere from the sky to the ravine belongs to her" (Gupta, 2014, p. 234). She loved her husband extremely and adhered to the "political faith as an act of faith toward him." (Spivak, 1981, p. 388) Thus, she obeyed the instructions given by the "gentleman revolutionaries" like Arijit, Jugal, Satish or Prabir, did 
not fetch Dulna's corpse, remained the most trustworthy courier of the fugitive leaders and became a competent link between the urban rebels' intelligence and the inbred survival skills of the harvesters and tribals.

However, Dopdi was defeated by the Senanayak's perspicacity as two hundred rupees was declared as the reward in her name and, to any poor starving villager; the amount appeared lucrative no doubt. Moreover, there were secret agents and the kin of the enemies spying her movements. Therefore, in spite of being disguised as Upi Mejhen, she was apprehended by the army with the help of Rotoni Sahu, the brother of Surja Sahu, and, two half-bred tribals named Shomai and Budhna. Following the training of the leaders that "no comrade will let the others be destroyed for her own sake" (Ibid, p. 400) and remembering her dead husband, she silently took oath not to disclose anything about the rebellious activities: "I swear by my life. By my life Dulna, by my life. Nothing must be told." (Ibid, p. 399) Dopdi surrendered by ululating deeply as if to let the whole world know of the disaster:

"Dopdi spreads her arms, raises her face to the sky, turns toward the forest, and ululates with the force of her entire being. Once, twice, three times. At the third burst the birds in the trees at the outskirts of the forest awake and flap their wings. The echo of the call travels far."(Ibid, p. 401)

When the army took someone into their custody, to unearth hidden facts they applied some methods that often involve brutal corporal and psychological assaults. But when the person is a woman the torture takes a gendered turn and thus we find that Dopdi's one-hour enquiry period in the army camp was inevitably followed by the period of gang-rape continuing throughout the night. Dopdi here comes closer to her archetype as the epical Draupadi had to confront this gendered subjugation in the Kaurava court by Duryodhana and his group. Draupadi's public molestation in the epic caters to diverse shades of powerpolitics - the epic-poet depicts how helpless she has been when she is being forced to come before the Kuru-assembly: she is in her menstruation, wearing only one piece of cloth, living in the Kaurava-house as a guest, and then, unexpectedly she is informed that she has been turned into a slave though she has five husbands no one can protect her: "nathvatianathvat". Her existence as a woman makes her an easy pawn for the Kauravas to assert their authority - the epic very incisively insinuates that while Duryodhana, at Karna's provocation, shows his thighs to Draupadi, his hidden intention is to damage the spirits of the Pandavas, specially of Bhima's, by molesting their common wife "bhimamādharshayanniva":

"Duryodhana. desirous of encouraging the son of Radha and insulting Bhima, quickly uncovered his left thigh that was like unto the stem of a plantain tree or the trunk of an elephant and which was graced with every auspicious sign and endued with the strength of thunder, and showed it to Draupadi in her very sight." (Ganguly, Bk I, p. 375)

In the court Draupadi's complaint, her cross-questioning regarding one's fundamental rights as a femaleand her intellectual speeches are, in effect, the rebellious voice that talks of the elementary rights of women and slaves, their merciless subjugation by various prevailing agencies and the scheming tactics of the law-making authorities to perpetuate their rule.

However, there are certain differences between the two texts: the epical Draupadi had to face the threat of rape which was eventually prevented by the divine intervention of Krishna whereas Dopdi had to endure multiple rapes by army personnel and no divine help 
came from anywhere. While Draupadi was molested in front of her five husbands, Dopdi confronted male oppression when her husband was absent forever. Thus Devi's Dopdi refutes the epical description, such as, "nathvatianathvat" and locating herself "first in a comradely, activist, monogamous marriage and then in a situation of multiple rape" (ibid, p. 387) she gathered her courage to face the situation from her consciousness that she would have to fight against it all by herself.

In fact, the story is a relocation of the ancient myth, and Spivak's precise judgement is noteworthy here:

"It would be a mistake, I think, to read the modern story as a refutation of the ancient. Dopdi is (as heroic as) Draupadi. She is also what Draupadi-written into the patriarchal and authoritative sacred text as proof of male power-could not be. Dopdi is at once a palimpsest and a contradiction." (ibid, p. 388)

Both the characters are intelligent, indomitable, strategic, and radical. Both are portrayed as epitomes of Shakti - the feminine power rather than the conventional forms like mother/ daughter. In the epic, Draupadi tried to thwart the sexual abuse by pleading the perpetrator as well as by demanding ethical justifications of the actions of her husbands (particularly the eldest one) and also by their opponents. Being a Naxalite insurrectionary Devi's Dopdi, on the other hand, gave vent to her anger and frustration through her resonant ululation, conjecturing about the imminent danger to her comrades-in-arms hiding in various strategically important locations throughout the Jharkhani forest range. It can also be seen as an act of her defiance against the possible scenario of her suffering inhuman brutalities in the hands of the state apparatus after her arrest. Ululation is a rural, womanly vocal exercise commonly practiced at the time of ritualistic ceremonies - yet it became the peculiar gesture of Dopdi's protest against the oppression. During her questioning hour she refused to reveal anything about the revolutionary movement, and then stubbornly endured the repeated lacerations by the male organ. Here Draupadi's legitimised polyandry is substituted by the multiple forceful rapes of Dopdi, happened under the directive of the Senanayak. However, in both the cases the statutory political power stayed latently supportive behind the sexual domination of the woman. The elderly wise men of Kuru-assembly did not intervene to stop the molestation of the Pandava-queen in The Mahabharata; in that same vein the state machinery neither did restrain its male members nor did provide enough protection to the women and 'rape' was executed as an effective weapon to subjugate particularly the female - in both the narratives, thus, the motif of 'rape' became "the culmination of her political punishment by the representatives of the law." (ibid, p. 388)

After the numerous physical assaults Dopdi's benumbed bare body was thrown on abed of straw at the army tent. And, in the morning, when the army chief commanded to fetch her, the moment became the instant of her resurrection. As she was offered water and cloth she threw the water and herself ripped her sari and confronted the Senanayak in open daylight with her blood-stained unclothed black body, lashing him with acid ironical voice: "The object of your search, Dopdi Mejhen. You asked them to make me up, don't you want to see how they made me?" (ibid, p. 402) The Senanayak was found bewildered at the incident and he howled at the guard crying why she was naked: "What is this? ...Where are her clothes?"(402) The guards were uneasy beforehand and related the shocking unprecedented happening: "Won't put them on, sir. Tearing them." (ibid, p. 404) Dopdi, instead of weeping and praying to the divinity, laughed aloud and wiping her bleeding lips, spoke "in a voice that is as terrifying, sky splitting, and sharp as her ululation": "What's the use of clothes? You can strip me, but how can you clothe me again? Are you a man?" While in the epic Draupadi could not be disrobed as she was bestowed with endless flow of clothes by Krishna, Dopdi adamantly stood undraped and confidently celebrated her femininity by nullifying the power of "the male organ / a gun" vis-à-vis the phallocentric ideology prevalent in our patriarchal 
and patronymic society. Spitting blood on the white bush shirt of Senanayak, Dopdi uttered resentfully:

There isn't a man here that I should be ashamed. I will not let you put my cloth on me. What more can you do? Come on, counter me-come on, counter me-?(ibid, p. 402)

Thus, "rather than save her modesty though the implicit intervention of a benign and divine... comrade, the story insists that this is the place where male leadership stops." (ibid: 388) Dopdi, although an "unarmed target", appalled the army chief for the first time in hislife that had been spent successfully terminating enemies in theory and in practice-

"she emerges as the most powerful "subject", who still using the language of sexual "honor", can derisively call herself "the object of your search", whom the author can describe as a terrifying super object”. (ibid, p.388)

Draupadi/ Dopdi is an epitome of that "female subaltern consciousness whose instrumentality is so often seen to be crucial" (Landry and Maclean, 1996, p. 229) in the history of the rebellious mobilization, time and again occurred with the active participation of tribals and peasants in India. Though tribal uprisings against the British rule were actually never recognised as anti-colonial peoples' movements, different tribes were mobilised by various indigenous leaders to reinforce the nation's ongoing freedom struggle - we can mention the tribal rebellion led by Jitusanthal of Maldah in 1921 when the entire nation was in the middle of the non-violent non-cooperation movement advocated by Gandhiji and his followers. However, in case of peasant insurgency, the community-feeling has always proved to be momentous to fight deep-rooted feudal systems; here self-consciousness all the time merges with the class-consciousness as noted by Ranajit Guha: "[The tribe's] consciousness of itself as a body of insurgents was thus indistinguishable from its recognition of its ethnic self." (Guha, 1983, p. 286) Dopdi, as a "comrade" of the Naxalite movement, is "part of the undoing of the opposites intellectual-rural, tribalist-internationalist" (Spivak, 1981, p. 390), and, her ontological identity as a subaltern-feminine-self foregrounds her class-struggle without marginalising the gender-struggle. In fact, as a tribal woman, she took pride in her socio-cultural background of her race and it became her weaponry through which she fought back the oppressive military organization of the state. The story articulates how the "object" of patriarchal hunt transforms into a powerful "subject" by using the politics of sexuality, and, here we can remember Derrida: "sometimes by contrast the woman by giving herself, gives-herself-as, and thus simulates and assures for herself possessivemastery...”(Derrida, 1978, pp. 109-11)

Following Spivak, Mahasweta Devi's Draupadi can be seen as a "project to retrieve the subaltern consciousness as the attempt to undo a massive historiographic metalepsis and "situate" the effect of the subject as subaltern... as a strategic use of positivist essentialism in a scrupulously visible political interest." (Landry and Maclean, 1996, p. 214)

Mahasweta was, during her lifetime, simultaneously a columnist of various journals as well asa litterateur producing numerous stories, novels and essays. She had close communion with the neglected and exploited tribal and rural peoples of India, and her writing became the emblem of her condemnation of the unending State-oppression of the indigenous population of the country. Repeatedly she said that she believes in the recording of the time and documenting the present situation like an undeceived dispassionate annotator, and, through her texts she relentlessly revealed the hunger, landlessness, and the neo-colonial 
enterprises in the form of the customs of debt-labour or bonded-labour rampant in the life of the poor peasantry even after independence. In the course of doing that she blended oral history, mythology, folklore, the official language, the regional vernaculars, colloquial speeches and slangs, and, by actively participating and intervening in the practical day-to-day living of people, consequently emerged as a "female organic intellectual of unusual ethical responsibleness, elaborated as a permanent persuader type" (ibid: 282) In her works repressions of gender and class are fused together and female characters like Draupadi become a potent voice of resistance against that. As Mahasweta told G. Collu:

I respect Indian tribals because they are much more civilized and sophisticated than we are. Their own social codes say... a woman's place is of honour... they are people all India has exploited like anything because they are black, because they don't speak the language. Draupadi is much more of a woman, much more polished, courageous than many others.(Collu, 1998, pp.147-148)

Indeed, as a resilient tribal Naxalite woman fighter, Draupadi/ Dopdi introduces herself as a true "organic intellectual" in her final laughter, as elucidated by Spivak elsewhere:

When the subaltern "speaks" in order to be heard and gets into the structure of responsible (responding and being responded to) resistance, heor she is on the way to becoming an organic intellectual.(Landry and Maclean, 1996, p. 271)

In Draupadi, Mahasweta offered an "affirmative deconstruction" by way of treating the epical myth of 'Draupadi' as a heterogeneous signifier and by transplanting the sign from its archetypal context to the contemporaneity. It is a kind of re-reading - "double reading"in order to undermine the dominant phallogocentric interpretations. That is why we find the subversion of male-centric hegemonic perceptions regarding subject-formation by means of Dopdi's last question on masculinity: “Are you a man?" leading to her ultimate words i.e. "Come on, counter me" stated as the subaltern's final counterpoise.

Mahasweta Devi frequently expressed her concerns about a historical sense mandatory for literary creations:

I always believed in History. Whatever is happening today is also history, and past days were actually much like modern times... Whatever elements can be found from going through all the Puranas orhistories, must be seen at modern times, too... in the ancient times class exploitation was there, class oppression was also there... one portion of the society will perpetually remain labourers or slaves. That part will forever produce materials while others will make profit out of it... (Gupta, 2014, p. 559)

Such historical sense - that historical implication related to the day-to-day societal existence of the masses - constantly motivated her while writing pieces like Aranyer Adhikar, Hajar Churashir Ma, Operation? Basai Tudu, Agnigarbha, Stanadayini and so on. Draupadi, as a part of such line of literary creations, reflects the historical time between 1960s and 1970s, especially 1967, when there were violent peasant and tribal insurgencies against the feudal landlordism in West Bengal and in some other parts of the whole country as well. In the story, characters like Dopdi Mejhen or her husband Dulna Majhi are representatives of the rebellious tribals while people like Arijit or Prabir are suggestive of the young urban educated men and women who took part in that uprising to help peasants get back their own lands. The text is introspective about the pros and cons of the movement, for instance, the union of the academic learning and the native guerrilla war techniques, the collusion between state legislative authorities and the military organization, the subterfuge of the rebels, the 
perfidy among the insurgents, the barbaric tortures by the army and police on the fugitives in custody, especially when they happened to be women. Mahasweta herself found in Draupadi and the Senanayak the practical correspondence to the female Naxalite like Archana Guha, and the infamous police officer like Runu Guha Niyogi:

During the Naxalite movement in the seventies there was a notorious police officer who especially took delight in arresting Naxalite women and torturing them barbarously. One Naxalite woman became almost an invalid. Amnesty International... moved her to some other country. She was cured and she came back and filed a case against this police officer... he lost in the end... that way she avenged Draupadi. (Collu, 1998, pp. 146-147)

In this way, Draupadi is a counter-narrative of that particular period, and, also, of the earlier periods replete with similar incidents of class-caste-ethnic-gender repressions. Essentially, Mahasweta turned up to be the new kind of realistic historian, to whom, according to Hayden White,

history was less an end in itself than a preparation for amore perfect understanding and acceptance of the individual's responsibility in the fashioning of the common humanity of the future... promoting a more realistic awarenessof the uniqueness of the present age', and, making 'clear in what respects [the presentsocial system] resembles and in what it differs from the social system thatpreceded it; and to determine what was gained by that upheaval. (White, 1966, p.133)

Her ethics was, finally, a celebration of the plurality of interpretation found against the fixity of facts in order to intervene and counter the dominant "epistemic violence", exercised in silencing the "subaltern".

\section{References}

Chakravarty, Radha (2008). Feminism and Contemporary Women Writers: Rethinking Subjectivity. Routledge.

Chakravorty, Spivak Gayatri. (1985). Three Women's Texts and a Critique of Imperialism. Critical Inquiry, Vol. 12, No. 1, "Race," Writing, and Difference, 243-261.

---.(1988). Can the Subaltern Speak? In Cary Nelson and Lawrence, Grossberg (Eds.) Marxism and the Interpretation of Culture. Macmillan.

Collu, Gabrielle. (1998). Speaking with Mahasweta Devi: Mahasweta Devi. Journal of Commonwealth Literature, 33, 2, pp.143-48.

Derrida, Jacques. (1978). Spurs. (Barbara Harlow, Trans.). University of Chicago Press.

Devi Mahasveta. (1981). Draupadi. (Gayatri Chakravorty Spivak, Trans.). Critical Inquiry, Vol.8, No. 2, Writing and Sexual Difference, pp. 381-402.

Ganguli, Kisari Mohan. (2008). 'The Mahabharata' of Krishna-Dwaipayana Vyasa, Volume-1. (Trans.). Munshiram Manoharlal Publishers Pvt. Ltd.

Guha, Ranajit. (1982). Subaltern Studies I: Writings on South Asian History and Society. OUP.

Gupta, Ajay. (2014). Selected Works of Mahasweta Devi (Ed.). Dey's Publishing.

Landry Donna and Gerald Maclean (1996). The Spivak Reade. (Eds.) Routledge.

Rekha. (2010).The Poetics and Politics of Space: A Reading of Mahasweta Devi's Subaltern Stories. Indian Literature, Vol. 54, No. 6 (260) (November/December), pp.143-160.

Salgado Minoli. (2015). Tribal Stories, Scribal Worlds: Mahasweta Devi and the Unreliable 
Translator. The University of Iowa Libraries. http: //jcl.sagepub.com/

White, Hayden V. (1973). Metahistory: The Historical Imagination in Nineteenth-Century

Europe. Johns Hopkins University Press.

- - (1966). The Burden of History. History and Theory, vol 5, issue 2, pp. 111-134.

\section{$\underline{\text { Bio-note }}$}

Shangsita Goswami is presently pursuing her Ph.D. from Visva-Bharati, Santiniketan. She has completed her graduation with Honours in English Literature from A.B.N. Seal College, University of North Bengal, her post-graduation from Banaras Hindu University and her M.Phil. from University of North Bengal again. She has done by B.Ed. from Indira Gandhi National Open University. She has been working in a Govt. aided Higher Secondary school since 11 years as an Assistant Teacher in English in West Bengal.

Email: rupumail@gmail.com 